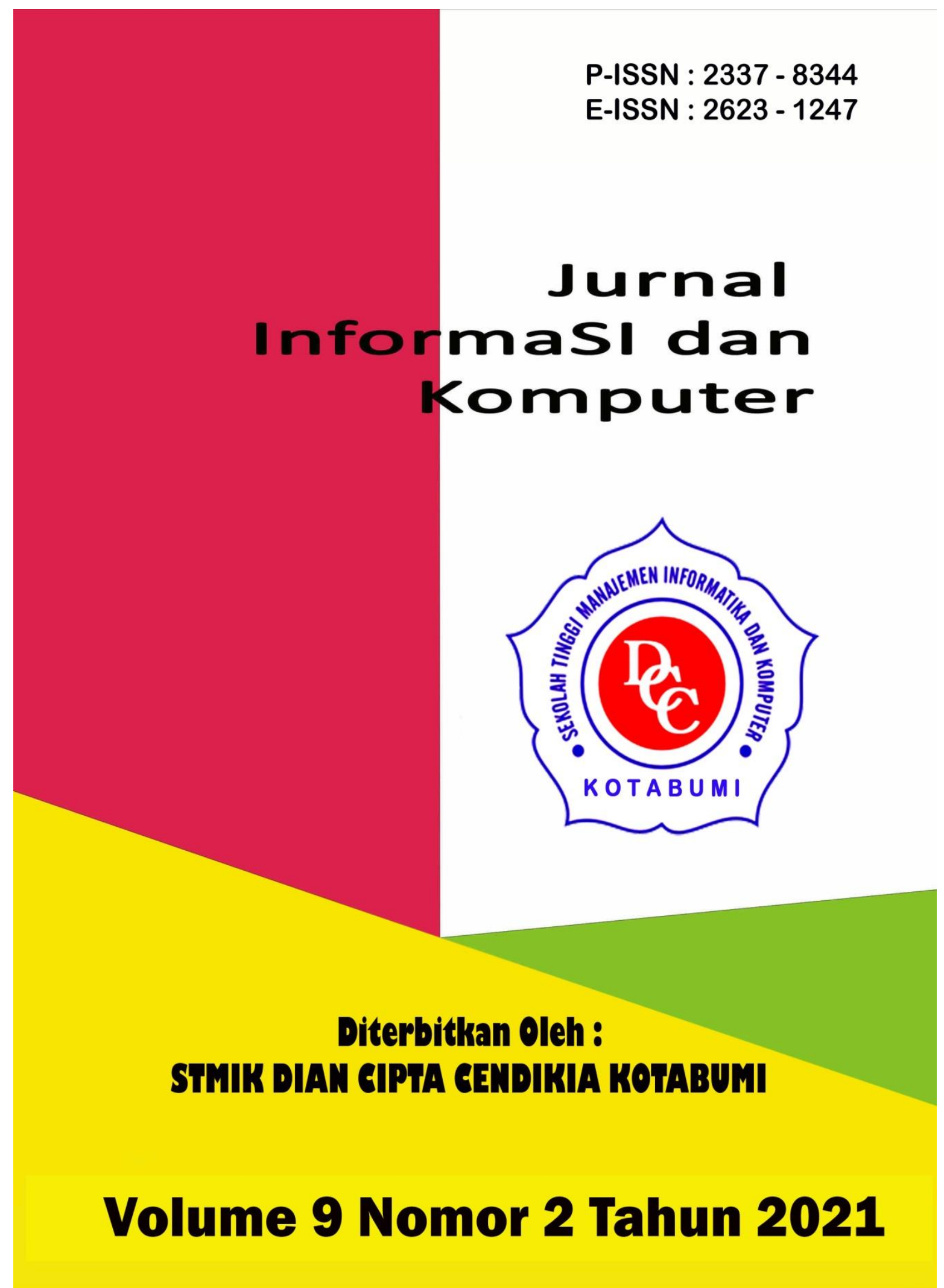




\section{Penerbit}

\section{Lembaga Penelitian STMIK Dian Cipta Cendikia Kotabumi}

Hak atas naskahh/tulisan tetap berada pada penulis, isi diluar tangung jawab penerbit dan Dewan Penyunting 


\section{PENGANTAR REDAKSI}

Puji syukur dipanjatkan kehadirat Tuhan Yang Maha Esa, atas karunia dan limpahan rahmatNYA jualah Jurnal Informasi dan komputer (JIK) STMIK Dian Cipta Cendikia Kotabumi ini dapat terwujud.Jurnal Informasi dan Komputer (JIK) yang terbit dua (2) kali dalam setahun ini merupakan suatu wadah untuk penyebar luasan hasil-hasil penelitian, studi pustaka, karya ilmiah yang berkaitan dengan Informasi dan Komputer khususnya bagi dosen-dosen STMIK Dian Cipta Cendikia Kotabumi serta umumnya para cendikiawan, praktisi, peneliti ilmu Informatika dan Komputer.

Harapan, dengan diterbitkannya Jurnal Informasi dan Komputer (JIK) ini sebagai salah satu bentuk sumbangan pemikiran dalam pengembangan ilmu informatika dan komputer yang berkaitan dengan kajian-kajian di bidang tekhnologi Informatik, Komunikasi Data dan Jaringan Komputer, perancangan dan Rekayasa Perangkat Lunak, serta ilmu-ilmu yang terkait dengan bidang Informasi dan Komputer lainnya.

Berkenaan dengan harapan tersebut, kepada para peneliti, dosen dan praktisi yang memiliki hasil-hasil penelitian, kajian pustaka, karya ilmiah dalam bidang tersebut diatas, dengan bangga redaksi Jurnal Informasi dan Komputer (JIK) menerima naskah ringkasan untuk dimuat pada jurnal Informasi dan Komputer (JIK) STMIK Dian Cipta Cendikia Kotabumi dengan berpedoman pada penulisan naskah jurnal sebagaimana dilampirkan pada halaman belakang (Bagian kulit dalam) buku jurnal ini.

Mutu dari suatu jurnal ilmiah tidak hanya ditentukan oleh para pengelolanya saja, tetapi para penulis dan pembaca jualah yang mempunyai peranan besar dalam meningkatkan mutu jurnal Informatika dan Komputer ini. Merujuk pada realita ini kamu sangat mengharapkan peran aktif dari peneliti untuk bersama-sama menjaga dan memelihara keberlangsungan dari jurnal Informasi dan Komputer STMIK Dian Cipta Cendikia Kotabumi ini. Yang juga tidak kalah pentingnya dari partisipasi tersebut diatas, adalah saran dan kritik yang membangun dari pembaca yang budiman agar kiranya dapat disampaikan langsung kepada redaksi JIK. Saran dan kritik yang membangun akan dijadikan masukan dan pertimbangan yang sangat berarti guna peningkatan mutu dan kualitas Jurnal Informasi dan Komputer STMIK Dian Cipta Cendikia Kotabumi.

Tak lupa diucapkan terima kasih yang tak terhingga atas perhatian dan kerjasama dari semua pihak yang tak dapat disebutkan satu persatu hingga dapat diterbitkan nya Jurnal Informasi dan Komputer (JIK) STMIK Dian Cipta Cendikia Kotabumi. Semoga apa yang telah diperbuat untuk kebaikan akan menjadi amal ibadah, amin.

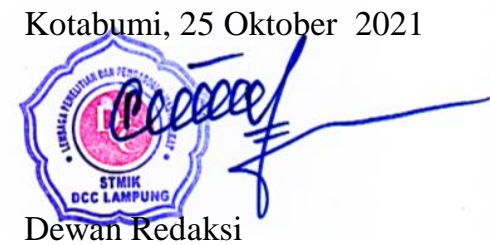




\section{JURNAL INFORMASI DAN KOMPUTER}

Volume 9 Nomor 2 Oktober 2021

Jurnal Informasi dan Komputer merupakan Sarana informasi ilmu pengetahuan, Tekhnologi dan Komunikasi yang berupa hasil penelitian, tulisan ilmiah, Ataupun studi pustaka. Jurnal ini terbit dua kali setahun pada bulan April dan Oktober. Berisi hasil penelitian ilmiah di bidang informatika yang bertujuan untuk menghubungkan adanya kesenjangan antar kemajuan teknologi dan hasil penelitian. Jurnal ini di terbitkan pertama kali pada tahun 2013.

Penanggung Jawab:

Ketua STMIK Dian Cipta Cendikia Kotabumi

\section{Pembina:}

Ketua STMIK Dian Cipta Cendikia Kotabumi Ketua Lembaga Penelitian STMIK Dian Cipta Cendikia Kotabumi

\section{Pimpinan Redaksi}

Dwi Marisa Efendi,.S.Kom.,M.Ti

\section{Redaksi pelaksana}

Rustam,.S.Kom,.M.Ti (STMIK Dian Cipta Cendikia Kotabumi)

Nurmayanti M.Kom (STMIK Dian Cipta Cendikia Kotabumi)

Sukatmi,.S.Kom., M.Kom (AMIK DCC Bandar Lampung)

Sampurna Dadi Riskiono,M.Kom (Universitas Teknokrat Indonesia)

Ifo Wahyu Pratama,S.Kom.,M.Ti(AMIK MASTER Lampung)

\section{Mitra Bestari}

Dr. RZ. ABDUL AZIZ, ST., MT (Institut Informatika dan Bisnis Darmajaya)

Dr. Dadang Sudrajat, S.Si, M.Kom (STMIK IKMI Cirebon)

Dr. Septafiansyah Dwi Putra, S.T., M.T (Politeknik Negeri Lampung)

Dr. Evi Grativiani, S.E., M.S.I (Universitas Sebelas Maret)

Rohmat Indra Borman ( Universitas Teknokrat Indonesia )

Ferry Wongso, S.KOm., M.Kom ( STMIK Darma Pala Riau)

Ferly Ardhy, S.Kom., M.Ti ( Universitas Aisyah Pringsewu )

Firmansyah, S.E., M.Si (STMIK Darma Pala Riau)
Amarudin (Universitas Teknokrat Indonesia)

Didi Susianto, S.T., M.Kom (AMIK Dian Cipta Cendika Bandar Lampung)

Alhibarsyah, St., M.Kom (STMIK Tunas

Bangsa Bandar Lampung)

Kemal Farouq Mauladi, S.Kom .M.Kom (Universitas Islam Lamongan)

Rima Mawarni, M.Kom ( STMIK Dian Cipta Cendikia Kotabumi)

Wira Jaya Hartono, S.Pd., M.Pd ( STMIK Darma Pala Riau)

Penerbit : STMIK Dian Cipta Cendikia Kotabumi Bekerja Sama Dengan LPPM STMIK Dian Cipta Cendikia Kotabumi.

\section{Alamat Redaksi/Penerbit:}

Jl. Negara No. 3 Candimas Kotabumi Lampung Utara

No Telpon/Fax 072423003

Email : 1ppm-stmik@dcc.ac.id 


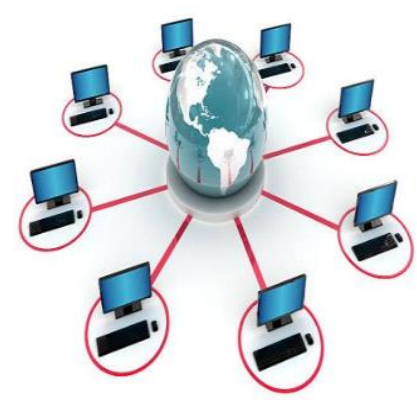

\section{JURNAL INFORMASI DAN KOMPUTER VOL. 9 NO. 2 THN. 2021}

\section{DAFTAR ISI}

Halaman

Sistem Informasi Akuntansi Persedian Barang Berbasis Web Pada Lembaga

Permasyarakatan Kelas II A Banceuy Bandung : "Kelompok Tani Desa Banjar Kertarahayu” Teuku Rian Hardiyansyah, Fatia Salsa Azzahra (Politeknik Piksi Ganesha Bandung ${ }^{1,2}$ ).

Penerapan Finite State Automata Pada Vending Machine Penjual Obat Non Resep

Dokter Dan Keperluan Medis

Eko Supriyanto $^{1}$, Angga Ardiansyah ${ }^{2}$, Frieyadie $^{3}$, Sri Rahayu ${ }^{4}$, Windu Gata ${ }^{5}$

(Universitas Nusa Mandiri ${ }^{12}$ )

Sistem Pendukung Keputusan Untuk Menentukan Kelayakan Pengajuan Sertifikasi Guru Dengan Metode Simple Additive Weighting (Studi Kasus : Ma Al Muhajirin Janti Jogoroto Jombang)

Budiman, umam baharudin, winarti

(Universitas Darul 'Ulum Jombang)

Perancangan Infrastruktur Domain Name Server Lokal Menggunakan Ubuntu Server 16.04

Pada PT. Xyz

Zaenal Mutaqin Subekti, Hendra Setiawan, Satria, Widia Murni Wijaya,

Aliy Hafiz, Warsudi

(STMIK Bani Saleh, Universitas Negeri Yogyakarta, AMIK Dian Cipta Cendikia,

STMIK MIC CIkarang)

Perancangan Sistem Informasi Idea Proposal (Ip) Berbasis Web Pada Pt. Paxel Algorita Unggul

Julian Murhan Sahputra, Indah Purnamasari

(Universitas Nusa Mandiri ${ }^{12}$ )

Sistem Pendukung Keputusan Untuk Menentukan Ekstrakurikuler Atletik

Berdasarkan Bakat Siswa Menggunakan Metode Profile Matching

Agnes Basuki, Petrus Sokibi, Tiara Eka Putri

(Universitas Catur Insan Cendekia)

Penerapan Algoritma K-Means Untuk Pengelompokan Usia Calon Penerima Vaksin

Di Kab. Ngawi

Irna Yuniarfi, Saifulloh

(Universitas PGRI Madiun ${ }^{12}$ )

System Penilaian Seleksi Calon Karyawan Baru Menggunakan Metode Simple Additive Weighting (SAW) Di PT.TNA

Anik Sri Wahyuningsih, Yudhi Firmansyah

(Universitas Panca Sakti Bekasi ) 
Perancangan Sistem Informasi Pembayaran SPP Menggunakan Framework Laravel Ichwan Habib Moudi

(Universitas Panca Sakti Bekasi)

Implementasi Algoritma K-Means Dan Algoritma Apriori Optimasi Kinerja Ecu

(Study Kasus Mobil Avanza Dan Xenia)

Sigit Mintoro' Asep Afandi

(STMIK Dian Cipta Cendikia Kotabumi)

Sistem Pakar Penyakit Buah Kakao Untuk Peningkatan Hasil Panen Kakao Menggunakan

Metode Case Base Reasoning (CBR) Berbasis Web Mobile

Aliy hafiz, Verawati

(AMIK Dian Cipta Cendikia,Bandar Lampung)

Penerapan Metode Rapid Application Develomment (RAD) Dalam Pengembangan

Sistem Pemesanan Menu Berbasis Android

Aris Baihaqi, Tumini

(Fakultas Sains dan Teknologi ${ }^{1,2}$ )

Rancang Bangun Sistem Informasi Geografis Pariwisata Di Lampung Timur

Sukatmi, Rexa Alfa Rizi

(AMIK DCC Bandar Lampung ${ }^{12}$ )

Implementasi Psak No. 45 Pada Proses Penyusunan Laporan Keuangan Menggunakan

M.S. Excel Dan Aplikasi Accurate Accouting Pada STMIK Bani Saleh

Marhakim, Willy Adam

(STMIK Bani Saleh ${ }^{12}$ )

Sistem Prediksi Harga KOPI LAMBAR ( Lampung Barat) Dengan Metode

Backpropagation, dan Double Exponential ( Studi Kasus BUMDES )

Supriyanto, Dwi marisa Efendi,Rhomadhon

(STMIK Dian Cipta cendikia Kotabumi ${ }^{1-}$ )

Sistem Informasi Pemasaran Produk Umkm Berbasis Web Pada Kecamatan Bumi

Nabung Lampung Tengah

Yuli Syafitri, Agus Prasetyo, Reni Astika

(AMIK Dian Cipta Cendikia Bandar Lampung)

Rancang Bangun Aplikasi Pembelajaran Aksara Lampung Berbasis Android

Ferly Ardhy, Hendra Syahrobi

(Universitas Aisyah Pringewu ${ }^{1,}$ STMIK Dian Cipta Cendikia ${ }^{2}$ )

Sistem Pakar Diagnosa Penyakit Kulit Pada Balita Menggunakan Metode Naïve

Bayes Dan Forward Chaining Studi Kasus Puskesmas Cempaka Sungkai Selatan

Sidik Rahmatullah, Rima Mawarni

(STMIK Dian Cipta Cendikia Kotabumi ${ }^{12}$ )

Rekayasa Perangkat Lunak Perhitungan Harga Pokok Produksi Metode

Full Costing Pada Umkm Mitra Cake Di Bandar Lampung

Pitrawati, Arif Sanjaya

(AMIK Dian Cipta Cendikia, Bandar Lampung) 
Rancang Bangun Sistem Ujian Online Menggunakan Algoritma Cosine Similarity

Berbasis Web

Haryono, Zaenal Mutaqin Subekti, Widiyawati, Hidayatullah

(STMIK Bani Saleh ${ }^{1234}$ )

Model Aplikasi Helpdesk Ticketing System Berbasis Web Menggunakan Metode Rad

Indra Permana

Pattern Recognition Tulisan Tangan Huruf Hijaiyah Menggunakan Metode

Convolutional Neural Network (CNN)

Mufassiril Abror, Nopiyanto

(Universitas Panca Sakti Bekasi ${ }^{12}$ )

Aplikasi Sistem Informasi Keuangan Berbasis Android Di Perumahan Taman

Karang Bahagia

Melda Ayulestari

(Universitas Panca Sakti Bekasi)

Audit Pelayanan Sistem Rujukan Online Puskesmas Menggunakan Framework COBIT 5.0

Nurmayanti, Merri Parida, Ngajiyanto, Ina Anzalna

(STMIK Dian Cipta Cendikia Kotabumi ${ }^{1234}$ )

Perancangan Sistem Informasi Pengolahan Data Nilai Siswa Berbasis Web

Erin Ermawati, Anik Sri Wahyuningsih

(Fakultas Sain dan Teknologi, Universitas Panca Sakti Bekasi ${ }^{12}$ )

Pengembangan Sistem Pelaporan Data Hasil Inspeksi Barang Berbasis Web

Siska Putriani

(Universitas Pancasakti Bekasi)

Penerapan Extreme Programming Dalam Perancangan Aplikasi Web Food Market

Tumini, Hilman Septiana

(Fakultas Sains dan Teknologi Universitas Panca Sakti Bekasi ${ }^{1,2}$ )

Sistem Pencarian Barang Berbasis Website Menggunakan Php Dan Mysql

Studi Kasus PT. Surya Technology Industri Sulaeman

(Universitas Panca Sakti Bekasi)

Implementasi Metode Prototype Pada Sistem Peminjaman Alat Kerja Berbasis Web

Di PT SK Metalindo

Ali Mulyanto, Arjun Gunawan

(Univeritas Panca Sakti Bekasi)

Aplikasi Tata Cara Wudhu Menggunakan Teknologi Augmented Reality

Sebagai Media Pembelajaran Di TK Al Fatih

Ahmad Yakub , Idarul Fadli

(Universitas Panca Sakti Bekasi ${ }^{12}$ )

Sistem Pakar Diagnosa Penyakit Ayam Petelur Menggunakan Metode Certainty Factor

Berbasis Web Mochammad

Taufiq Hidayat, Ali Mulyanto

(Universitas Panca Sakti Bekasi ${ }^{12}$ ) 
Penerapan Metode Prototyping Dalam Perhitungan Hasil Produksi Menggunakan

Arduino Uno R3 Dan Php Di PT. Indonesia Epson Industry

Amandha Aulia, Ajar Rohmanu

(Universitas Panca Sakti Bekasi ${ }^{12}$ )

System Pendukung Keputusan Penentuan Guru Teladan Dengan Metode Profile Matching

Hasbulloh, Agmawarnida

(Universitas Panca Sakti Bekasi ${ }^{1,2}$ )

Implementasi Waterfall Method Pada Aplikasi Buku Induk Siswa Berbasis Web

Idam Holid, Yogie Krisnayadi

(Universitas Panca Sakti ${ }^{12}$ )

Pengembangan Text To Speech Media Pembelajaran Untuk Pengenalan

Anggota Tubuh Manusia Kelas V Sekolah Dasar

Juwanda Saputra, Ali Mulianto

(Teknik Infomratika Fakulutas Sains dan Teknologi ${ }^{12}$ )

Perancangan Sistem Peminjaman Barang Berupa Aset Tetap Berbasis Web

Pada Lembaga Permasyarakatan Kelas II A Banceuy Bandung

Guntur Salasa Priambodo, Perwito, Candra Mecca Sufyana

(Politeknik Piksi Ganesha Bandung ${ }^{1,2,3}$ )

Metode Pemilihan Karyawan Terbaik Sebagai Penentu Goodwill Perguruan Tinggi

Dengan Menggunakan Metode Topsis (Studi Kasus Perguruan Tinggi Di Lampung Utara)

Dwi Sartika, Pakarti Riswanto

(STMIK Dian Cipta Cendikia Kotabumi)

Sistem Pendukung Keputusan Pemilihan Merek Smartphone Menggunakan

Metode Analytical Hierarchy Process (AHP)

Ade Kiki Fatmawati, Muhammad Sultan Raflie, Norma Yunita

(Universitas Nusa Mandiri ${ }^{123}$ )

Pattern Recognition Aksara Lampung Menggunakan Algoritma Neural Network

Metode Analytical Hierarchy Process (AHP)

Nopiyanto, Rahmadi

(Universitas Panca Sakti Bekasi) 


\title{
SISTEM PENCARIAN BARANG BERBASIS WEBSITE MENGGUNAKAN PHP DAN MYSQL STUDI KASUS PT.SURYA TECHNOLOGY INDUSTRI
}

\author{
Sulaeman \\ Universitas Panca Sakti Bekasi \\ J1. Kapten Sumantri No.16, Cikarang Utara, Bekasi, Jawa Barat 17530 \\ Email : sulaeman585@gmail.com
}

\begin{abstract}
ABSTRAK
Pada era teknologi informasi seperti sekarang ini, efisiensi waktu dan tenaga, serta kemudahan dalam mendapatkan suatu informasi sangatlah dibutuhkan. Setiap perusahaan pasti menginginkan untuk mempermudah sistem kerja dalam hal produksi sampai ke pergudangan. Oleh karena itu, harus ditunjang dengan sarana dan prasarana yang memadai. PT. Surya Technology Industri terletak di jl. inti III blok c8 no.10 kawasan industri BIIE, cikarang selatan bekasi, Indonesia adalah bisnis yang bergerak di bidang Elektronik, Komponen 1dan Karet \& Plastik. Persediaan barang yang berada di bagian gudang sebuah perusahaan adalah yang yang sangat penting untuk menyediakan barang yang banyak untuk keperluan customer perusahaan. Namun dalam hal pengolahan data persediaan barang sebelumnya menggunakan sistem manual dengan memakai buku sebagai media panduan part namber dan nama barang, sehingga memakan banyak waktu untuk mencari keberadaan barang yang dibutuhkan dan sering kali proses pengriman bermasalah saat sampai custamer dilihat dari banyaknya masalah yang timbul akan memberikan sedikit sekali keuntungan bagi perusahaan.dari masalah yang penulis temukan . Maka penulis merancang sistem untuk memudahkan dan membuat solusi pada masalah tersebut ialah penulis membuat "Sistem Pencarian Barang Berbasis Website Menggunakan Php dan MySQL Studi Kasus PT.Surya Technology Industri” dengan adanya dibuat sistem tersebut untuk memudahkan para pekerja atau karyawan yang bertugas untuk mencari data barang yang tersedia dengan waktu yang cukup efesien. Website adalah basis untuk mebuat sistem tersebut dengan menggunakan php sebagai pemrograman yang akan membuat sistem dan MySQL sebagai database barang yang berada di gudang. Maka dengan ini semoga dapat bermanfaat dan memudahkan karyawan pada proses pencarian data barang dan mencari barang tersebut.
\end{abstract}

Kata Kunci : Sistem, Data Barang, Pencarian, Php, MySQL

\begin{abstract}
S
In the era of information technology as it is today, the efficiency of time and energy, as well as the ease of obtaining information is very much needed. Every company would want to simplify the work system in terms of production to warehousing. Therefore, it must be supported by adequate facilities and infrastructure. PT. Surya Technology Industri is located at jl. core III block c8 no.10 BIIE industrial area, Cikarang Selatan Bekasi, Indonesia is a business engaged in Electronics, Component 1 and Rubber $\&$ Plastics. The inventory of goods in the warehouse of a company is very important to provide a lot of goods for the needs of the company's customers. However, in terms of processing inventory data previously using a manual system by using books as a media guide for part number and item names, so it takes a lot of time to find the whereabouts of the items needed and often the delivery process has problems when it comes to the customer, judging from the many problems that arise will give very little profit for the company. of the problems that the author found. So the author designed a system to make it easier and make a solution to this problem, the author made a "Website-Based Goods Search System Using Php and MySQL Case Study PT. Surya Technology Industri" with the existence of the system made to make it easier for workers or employees on duty to find data items available in an efficient manner. The website is the basis for making the system using php as the programming that will create the system and MYSQL as the database of goods in the warehouse. So with this hopefully it can be useful and make it easier for employees in the process of searching for item data and looking for these items.
\end{abstract}

Keyword s: System, Data Items, Search, Php, MySQL. 


\section{Pendahuluan}

Teknologi saat ini mengalami perkembangan yang sangat pesat, pekerjaan yang dulunya dilakukan dengan cara tradisional dan memerlukan banyak waktu dalam menyelesaikannya sekarang dapat dilakukan dengan bantuan peralatan yang canggih dan tidak memerlukan waktu yang terlalu lama dalam menyelesaikannya.

PT. Surya Technology Industri terletak di jl. inti III blok c8 no.10 kawasan industri BIIE, cikarang selatan bekasi, Indonesia adalah bisnis yang bergerak di bidang Elektronik, Komponen 1 dan Karet \& Plastik.

Persediaan barang yang berada di bagian gudang sebuah perusahaan adalah yang yang sangat penting untuk menyediakan barang yang banyak untuk keperluan customer perusahaan, namun dalam hal pengolahan data persediaan barang sebelumnya menggunakan sistem manual yaitu admin hanya mencatat di buku dan memasukkan data si excel saat buku catatan sudah banyak terisi dengan file yang kurang terstruktur, dengan penyimpanan yang kurang efisien dan jika masih belum di input oleh admin, sehingga admin saat dapat intruksi mencari data barang maka melihat catatan terlebih dahulu kemudia laporkan ke leader, sehingga memakan banyak waktu untuk mencari keberadaan barang yang dibutuhkan dan sering kali proses pengriman bermasalah saat sampai customer dilihat dari banyaknya masalah yang timbul akan memberikan sedikit keuntungan bagi perusahaan.

Berdasarkan dari latar belakang di atas penulis melakukan penelitian bersama tentang sistem informasi yang dapat membantu dalam pengolahan data dan aktual yaitu "Sistem Pencarian Barang Berbasis Website Menggunakan Php dan MySQL Studi Kasus PT.Surya Technology Industri" yang bertujuan untuk meminimalisir kesalalahan dalam pengambilan barang dan mempermudah produktifitas pekerja.

\section{METODE PENELITIAN}

\subsection{Waterfall}

Metode Waterfall adalah salah satu model dalam pengembangan sistem Rekayasa
Perangkat Lunak dimana klien dan pengembang dapat saling berkomunikasi dalam memenuhi kebutuhan sistem [8].

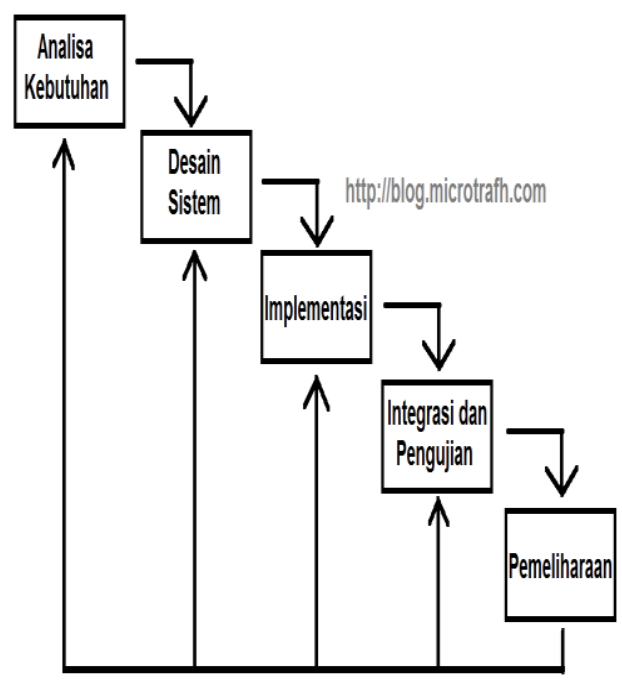

Gambar 3.1 Waterfall

\section{Tahapan Metode Penelitian}

\section{Analisa Sistem Kebutuhan}

Pada tahap ini objek penelitian di PT. Surya Technology Industri pada departemen gudang. Dengan wawancara pada pihak terkait mengenai masalah dan kebutuhan kemudia di ambil kesimpulan.

\section{Desain Sistem}

Dalam Tahapan proses ini yaitu pembuatan rancangan secara meneyluruh untuk tahap selanjtunya dikembangkan kembali. Pada tahap ini proses perancangan dilakukan dengan menggunakan dengan penggambaran diagram. Diagram yang dimaksud antara lain adalah Use Case Diagram, Activity Diagram,Sequence Diagram, Class Diagram serta perancangan alat untuk sistem pencarian barang berikut ini adalah tahapan perancanganya.

\section{a. Us Case Diagram Sistem Usulan}




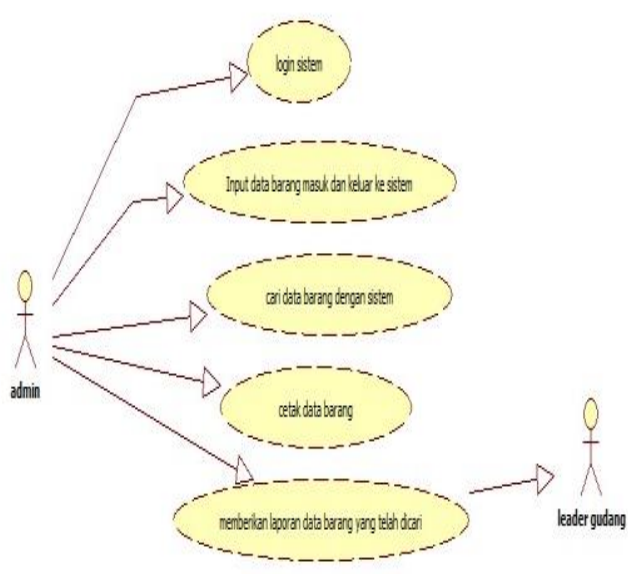

Gambar 3.2 Use Case Diagram Sistem Usulan

\section{b. Activity Diagram}

\section{Login}

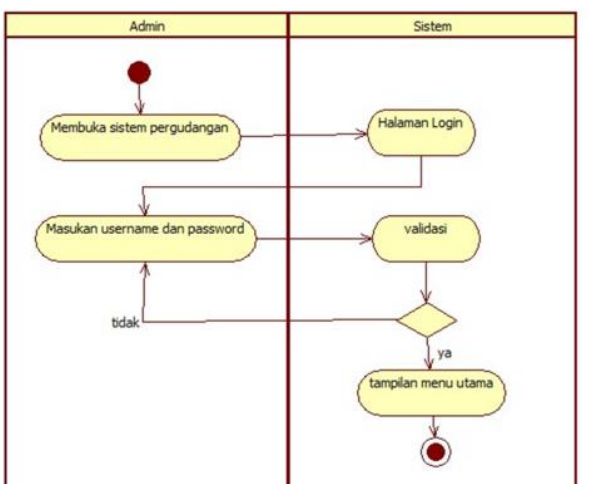

Gambar 3.3 Activity Diagram Login

\section{Proses input, pencarian dan output}

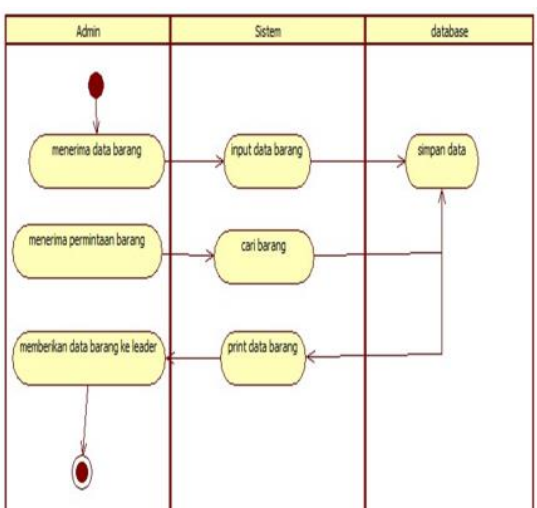

Gambar 3.3 Activity Diagram Proses input, pencarian dan output.

\section{c. Sequence Diagram}

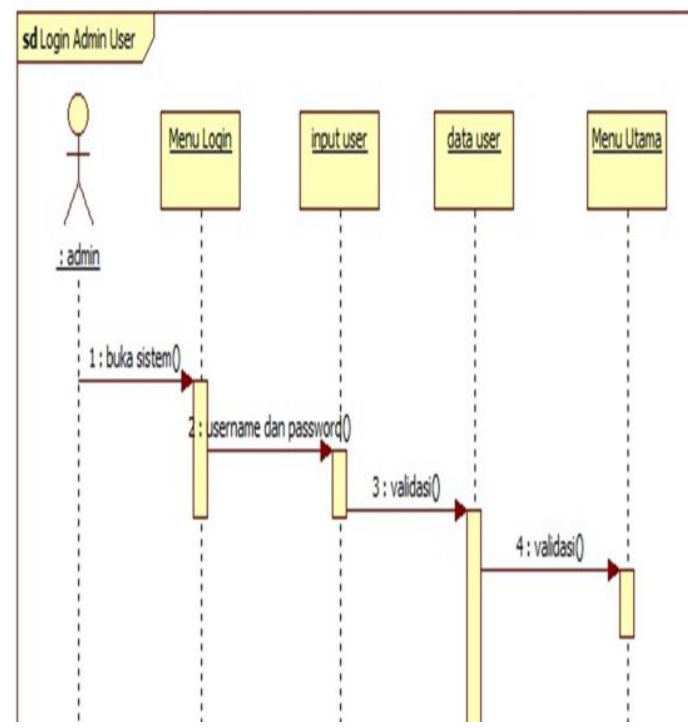

Gambar 3.4 Sequencse Diagram Login

1. proses input, pencarian dan output

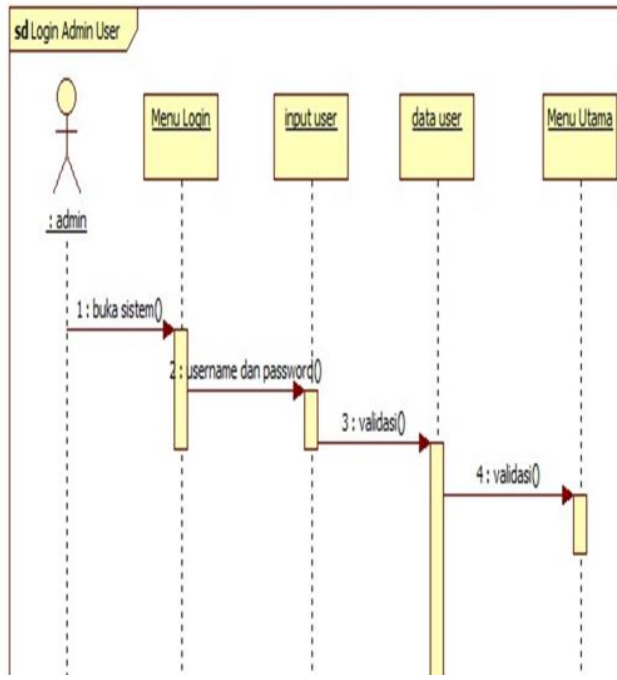

Gambar 3.5 Sequencse Diagram proses input, pencarian dan output. 


\section{d. Class Diagram}

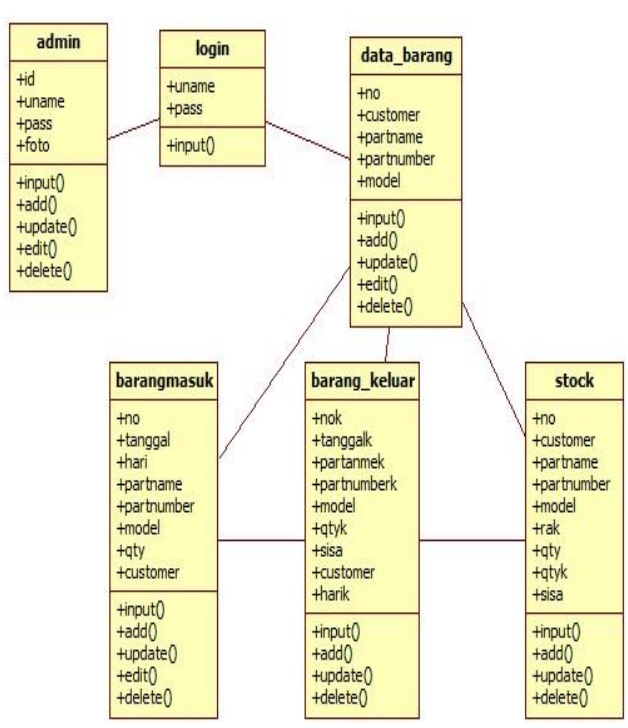

Gambar 3.6 Class Diagram Sistem Usulan

\section{Implementasi}

Implementasi sistem adalah sistem yang di buat dan telah jadi sesai dengan apa yang dibutuhkan dan di rancang . hasil sistem yang dibuat akan di tampilkan pada bab 3 di hasi dan pembahasan.

\section{Integrasi dan Pengujian}

Pada tahap ini pengujian sistem dilakukan dengan metode pengujian sistem black box adapun di antar pengujian yang dilakukan adalah sebagai berikut.

\section{a. Rancangan Pengujian}

Tabel 3. 7 Rancangan Pengujian

\begin{tabular}{|c|l|l|}
\hline \multicolumn{3}{|c|}{ Rancangan Pengujian } \\
\hline Kelas Uji & \multicolumn{1}{|c|}{ Detail Pengujian } & Jenis Pengujian \\
\hline Menu Login & $\begin{array}{l}\text { Verifikasi data Login } \\
\text { dan Hak Akses Login }\end{array}$ & Black Box \\
\hline Menu admin & $\begin{array}{l}\text { Proses menampilkan } \\
\text { data, fungsi tombol } \\
\text { dan input data }\end{array}$ & Black Box \\
\hline $\begin{array}{l}\text { Pencarian } \\
\text { Data }\end{array}$ & $\begin{array}{l}\text { Menampilkan output } \\
\text { data yang di cari }\end{array}$ & black Box \\
\hline
\end{tabular}

\section{b. Hasil Pengujian}

Tabel 3.8 Tabel Pengujian Login

\begin{tabular}{|c|c|c|c|c|}
\hline No & Skenario & Bagian di Uji & $\begin{array}{l}\text { Prosedur } \\
\text { Pengujian }\end{array}$ & $\begin{array}{l}\text { Hasil } \\
\text { Pengujian }\end{array}$ \\
\hline 1 & $\begin{array}{c}\text { username dan } \\
\text { password tidak } \\
\text { di isi }\end{array}$ & $\begin{array}{c}\text { user name dan } \\
\text { pass word tidak diisi }\end{array}$ & $\begin{array}{c}\text { Sistem } \\
\text { tidak } \\
\text { Menerima } \\
\text { login } \\
\text { dengan } \\
\text { password } \\
\text { kosong } \\
\end{array}$ & Berhasil \\
\hline 2 & $\begin{array}{l}\text { username dan } \\
\text { password di isi }\end{array}$ & $\begin{array}{l}\text { username : admin } \\
\text { password : admin }\end{array}$ & $\begin{array}{c}\text { sistem } \\
\text { menerima } \\
\text { pasword } \\
\text { dan } \\
\text { username } \\
\text { yang telah } \\
\text { terdaftar }\end{array}$ & Berhasil \\
\hline
\end{tabular}

Tabel 3.9Tabel Menu Admin

\begin{tabular}{|c|c|c|c|c|}
\hline No & Sekenario & Test Case & Hasil & Kesimpulan \\
\hline 1 & $\begin{array}{l}\text { Tombol } \\
\text { semua } \\
\text { menu }\end{array}$ & $\begin{array}{l}\text { klik tombol } \\
\text { menu } \\
\text { stock }\end{array}$ & $\begin{array}{l}\text { terbuka } \\
\text { menu } \\
\text { stock } \\
\text { tombol } \\
\text { CRUD } \\
\text { barang } \\
\text { serta } \\
\text { menampilk } \\
\text { an data }\end{array}$ & Valid \\
\hline 2 & $\begin{array}{l}\text { Tombol } \\
\text { input, } \\
\text { update, dan } \\
\text { hapus }\end{array}$ & $\begin{array}{l}\text { klik input, } \\
\text { update, } \\
\text { dan hapus } \\
\text { pada menu }\end{array}$ & $\begin{array}{l}\text { terbuka } \\
\text { form input } \\
\text {,data pada } \\
\text { setiap } \\
\text { menu yang } \\
\text { akan di } \\
\text { update dan } \\
\text { data } \\
\text { terhapus } \\
\text { data yang } \\
\text { di hapus }\end{array}$ & Valid \\
\hline 3 & $\begin{array}{l}\text { tombol } \\
\text { simpan }\end{array}$ & $\begin{array}{l}\text { klik tombol } \\
\text { simpan } \\
\text { pada } \\
\text { setiap } \\
\text { input data }\end{array}$ & $\begin{array}{l}\text { data } \\
\text { tersimpan } \\
\text { ke bas is } \\
\text { data }\end{array}$ & valid \\
\hline
\end{tabular}

Tabel 3.10 Pencarian Data

\begin{tabular}{|c|l|l|l|l|}
\hline No & Sekenario & Test Case & Hasil & Kesimpulan \\
\hline 1 & $\begin{array}{l}\text { pencarian } \\
\text { pada semua } \\
\text { menu }\end{array}$ & $\begin{array}{l}\text { ketik nama } \\
\text { barang }\end{array}$ & $\begin{array}{l}\text { muncul } \\
\text { data } \\
\text { barang } \\
\text { yang di } \\
\text { cari }\end{array}$ & Valid \\
\hline
\end{tabular}

\section{Pemeliharaan Sistem}

Pada tahap ini pemeliharaan sistem di lakukan pada setiap bulan untuk meminimalisir kesalhan-kesalahan pada sistem yang telah di 
buat serta memperbahrui sistem menjadi lebih baik.

\section{HASIL DAN PEMBAHASAN}

Hasil dan pembahasan akan akan menampilkan gambar berupas sistem yang dibuat.

\subsection{Aplikasi Sistem}

1. Tampilan Aplikasi Sistem

a. Login

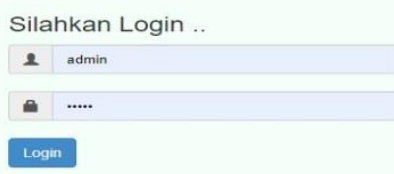

Gambar 4.1 login

\section{Tampilan Menu Utama}

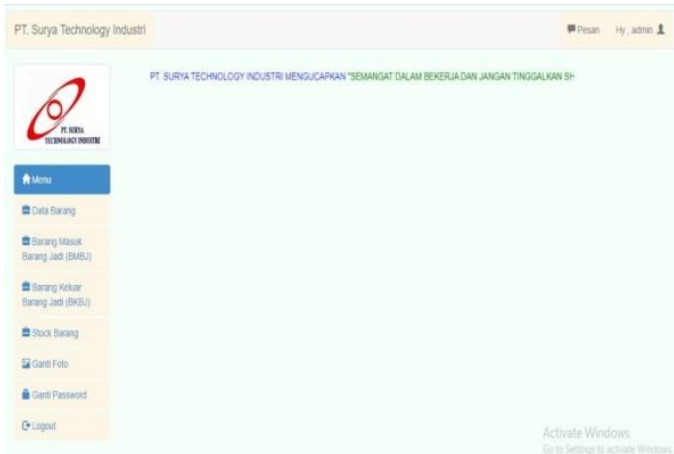

Gambar 4.2 Tampilan Menu Utama

\section{Tampilan Data}

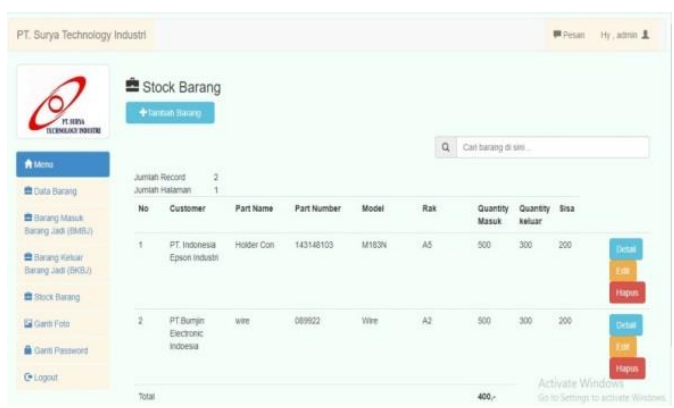

Gambar 4.3 Tampilan Data
3. Tampilan input

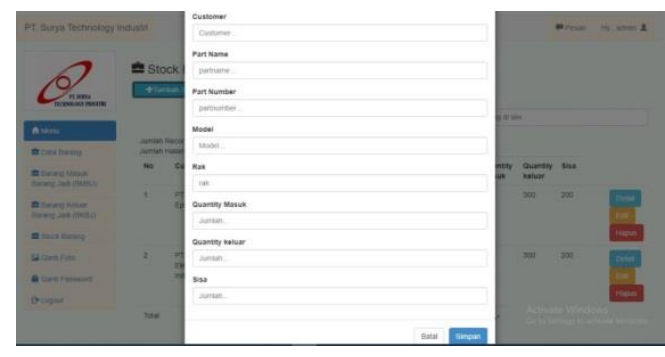

Gambar 4.4 Tampilan Input

\section{Tampilan detail}

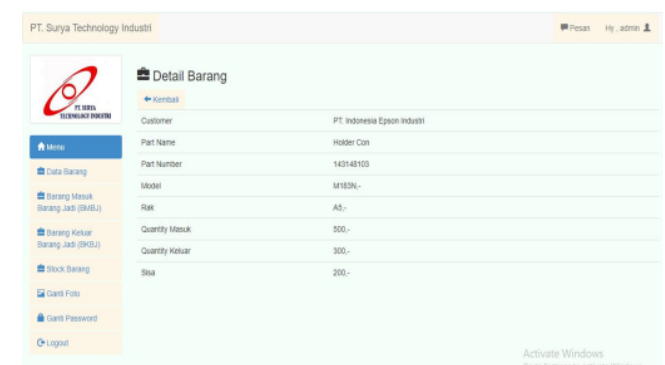

Gambar 4.5 Tampilan detail

\section{Tampilan Hapus}

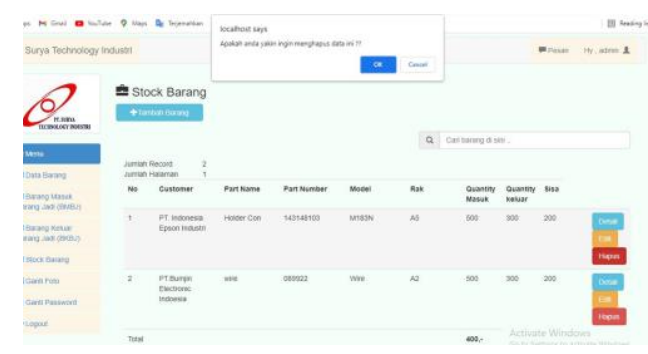

Gambar 4.6 Tampilan hapus

\section{Tampilan edit}

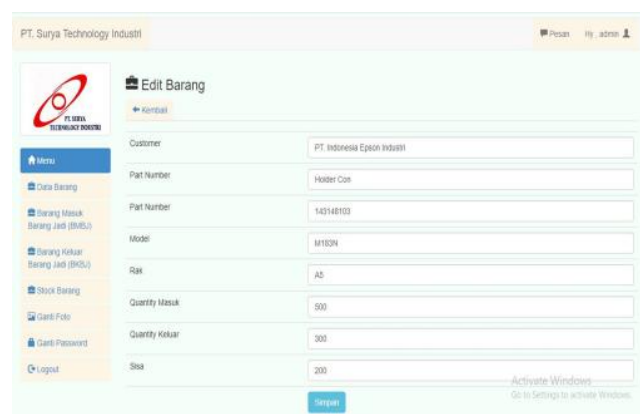

Gambar 4.7 Tampilan edit 


\section{Tampilan cari}

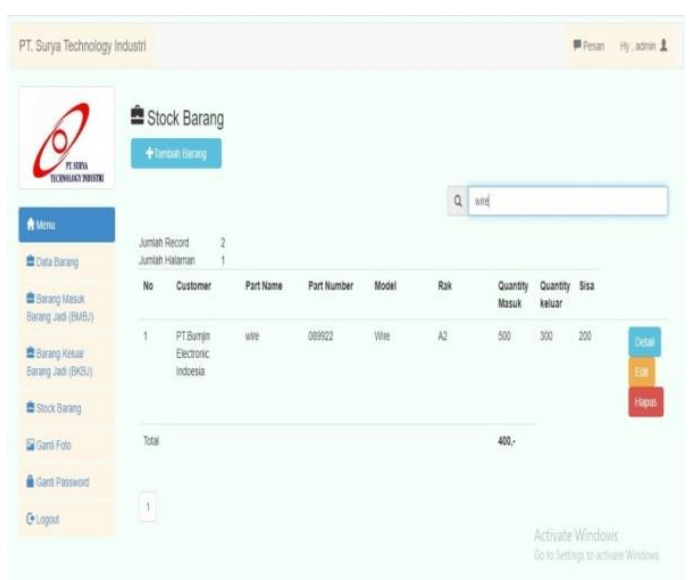

Gambar 4.8 Tampilan cari

\section{Tampilan output}

\begin{tabular}{|c|c|c|c|c|c|}
\hline $\begin{array}{l}\mathrm{N} \\
\mathrm{O}\end{array}$ & Pertanyaan & $\begin{array}{l}\mathrm{S} \\
\mathrm{S}\end{array}$ & $S$ & $\begin{array}{l}\mathrm{T} \\
\mathrm{S}\end{array}$ & $\begin{array}{l}\mathrm{S} \\
\mathrm{T}\end{array}$ \\
\hline \multicolumn{6}{|c|}{ Tampilan: } \\
\hline 1 & $\begin{array}{l}\text { Sistem ini mudah } \\
\text { digunakan }\end{array}$ & 5 & & & \\
\hline 2 & $\begin{array}{l}\text { Button sudah bekerja } \\
\text { sesuai dengan fungsinya }\end{array}$ & 4 & 1 & & \\
\hline 3 & $\begin{array}{l}\text { Keterangan kegunaan } \\
\text { menu dalam sistem sudah } \\
\text { jelas dan mudah bagi } \\
\text { pengguna }\end{array}$ & 1 & 4 & & \\
\hline 4 & $\begin{array}{l}\text { Kesinambungan dari satu } \\
\text { halaman ke halaman } \\
\text { berikutnya mudah } \\
\text { dilakukan }\end{array}$ & 4 & 1 & & \\
\hline \multicolumn{6}{|c|}{ Kegunaan : } \\
\hline 1 & 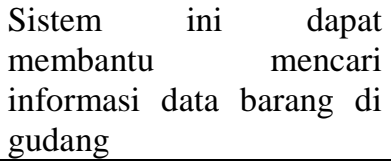 & 5 & & & \\
\hline 2 & $\begin{array}{l}\text { Sistem ini dapat } \\
\text { bermanfaat untuk } \\
\text { mengetahui barang }\end{array}$ & 5 & & & \\
\hline 3 & $\begin{array}{l}\text { Dapat melakukan proses } \\
\text { tambah dan edit data pada } \\
\text { menu admin }\end{array}$ & 5 & & & \\
\hline 4 & $\begin{array}{l}\text { Dapat melakukan proses } \\
\text { pelaporan yang efektif }\end{array}$ & 2 & 3 & & \\
\hline
\end{tabular}

Gambar 4.9 Tampilan output

\section{a. 4.2 Validasi Pengujian Sistem}

Dalam pengujian kelayakan sistem ini penulis menggunakan tahapan uji kelayakan kuesioner. Kuesioner merupakan daftar pertanyaan yang diajukan kepada responden untuk mencari jawaban dari permasalahan yang teliti.

Berdasarkan batasan masalah, penerapan metode waterfall dalam pengembangan sistem informasi pencarian barang pada gudang PT.Surya Technology Industri berbasis web menggunakan php dengan klarifikasi yang sesuai dengan target dari aplikasi tersebut setelah mencoba, mereka menjawab kuesioner untuk mengetahui presentase keberhasilan dari sistem ini.

Keterangan

1. $\mathrm{SS}=$ sangat setuju $=4$

2. $S=$ setuju $=3$

3. $\mathrm{TS}=$ tidak setuju $=2$

4. STS $=$ sangat tidak setuju $=1$

5. $\mathrm{Y}=$ Skor tertinggi likert $\mathrm{x}$ jumlah responden (Angka Tertinggi 5) "perhatikan bobot nilai"

F6 $\quad \mathrm{X}=$ Skor terendah likert $\mathrm{x}$ jumlah responden (Angka terendah 1) "perhatikan bobot nilai"

Rumus index $\%$ = total skor / Y x 100.

Tabel 4.1 Lembar kuesioner

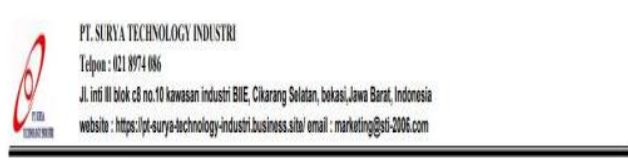

Laporan Data Barang

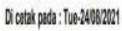

\begin{tabular}{|c|c|c|c|c|c|c|}
\hline 10 & Castomit & Pertlam & Pankunitor & Howal & aty hall & jimlth \\
\hline 1 & Prasind & nispipos & 123 & hithos & 0 & 0 \\
\hline 2 & quethe & towsove & 0 & wells & 12 & 12 \\
\hline 3 & PT. nánpation & tossot & 0 & sckos & 30 & 30 \\
\hline
\end{tabular}

Hasil perhitungan jawaban responden sebagai berikut :

1. Responden yang menjawab sangat setuju $(5)=10 \times 5=50$ 
2. Responden yang menjawab setuju (4) $=4 \times 9=72$

3. Responden yang menjawab tidak setuju (2) $=0 \times 2=0$

4. Responden yang menjawab tidak sangat setuju $(1)=0 \times 1=0$

5. Total Skor $=50+36+0+0=86$

Jumlah skor ideal untuk pertanyaan yang diajukan kepada responden :

A. Skor tertinggi (Y) : 5 x $30=120$ (sangat setuju)

B. Skor terendah (X) : 0x $40=40$ (sangat tidak setuju)

C. Interpretasi skor hasil pengamatan : $(86 / 120)$ $\mathrm{x} 100 \%=71,66 \%$.

Kesimpulan hasil jawaban kuesioner yang diberikan kepada orang yang terkait disimpulkan bahwa sistem ini layak untuk digunakan.

\section{KESIMPULAN}

Berdasarkan dari analisis yang penulis buat dengan sebenar-benarnya menghasilkan kesimpulan yaitu diantaranya.

1. Sistem yang di buat untuk memudahkan kinerja administrasi dan pihak lainnya yang berhubungan dengan pergudangan di perusahaan.

2. Sistem yang dibuat dengan berbasis web dapat digunakan di komputer siapa aja dimana aja dikarenakan sistem tidak membutuhkan ukuran file yang besar.

\section{DAFTAR PUSTAKA}

[1] I Putu Agus dan Eka, Pratama.(2014). "Sistem Informasi dan Implementasinya", Bandung: Informatika Bandung.

[2] Munir, Renaldi dan Lidya,Leoni.(2016). "Algoritma dan Pemrograman", Bandung: Informatika Bandung.

[3] Haerani, Reni dan Robiyanto.(2019). "sistem informasi pengolahan data nilai siswa berbasis web" Jurnal Sistem Informasi 6.2 (2019).

[4] Wardana (2016). "Aplikasi Website PROFESIONAL dengan PHP dan JQuery", Jakarta: Elex Media Coputindo.

[5] Deval Gusrion. (2018) "SISTEM PEMBAYARAN SECARA CASHLESS PADA KOPERASI SEKOLAH YAYASAN IGASAR" Jurnal KomtekInfo Vol 5 No 2 (2018)

[6] Yudie Irawan.( 2017). "Sistem Informasi Perpustakaan Berbasis Web" jurnal jsinbis 5.1 (2017).

[7] Rosa dan Shalahuddin, M. (2018). "Rekayasa Perangkat Lunak Terstruktur dan Berorientasi Objek", Bandung: Informatika. 